\title{
Soma rhei, or the New Vision of Porn
}

\author{
Tomasz Kaliściak, Tomasz Sikora
}

We are all libidos that are too viscous and too fluid.

(Deleuze and Guattari 67)

Each of us is fluid locked up in a fixed form.

(SUKA OFF, personal communication)

\begin{abstract}
NOTE: We would like to thank the SUKA OFF artists for permission to use stills from Carnal Fluidity to illustrate our essay. Given the fact that the movie is hardly summarizable in narrative terms and works mostly through the (highly fluid) visual medium, we felt that the images would do a much better job in conveying the film's (or individual scenes') impact than any contorted description would. The artists were also kind enough to answer a few questions for us; quotes from their responses are followed in the text by the acronym AS = the artists' statement.
\end{abstract}

During the 1990s "fluidity" became a postmodern catchword. For Zygmunt Bauman, for instance, the state of permanent liquidity defines the late, consumerist stage of modernity (Bauman passim). For numerous feminist, gender and queer authors, on the other hand, the (arguably liberating) concept of fluidity opened up new spaces for theorizing the end of fixed and stable bodies, genders, sexualities and identities. Related aspects of corporeality - such as Bakhtin's incomplete and grotesque bodies, Kristeva's "abject" - have been elaborated on quite extensively. Is it still possible to talk about fluidity without either repeating the hackneyed clichés or else dismissing the "postmodern follies" from, say, a sober Marxist position? As some might want to argue, the liberating capacities of the fluidity metaphor, if any, have reached their limits and at the end of the day it has proven to do little more than buy into the capitalistic logic that "liquidates" stable structures and leaves us vulnerable to a neoliberal re-modelling of socio-political relations. Others, however - including, notably, the editors of this issue of InterAlia - criticize the "fluidification project" for not being radical enough, for giving in to a resolidification and hygienicization of the 
corporeal, and for conforming to (however reconfigured or, indeed, fluidified) norms of propriety. Further explorations of the body's materiality promise to re-fluidify queer thinking and promote a "mucosal, suppurative and leaky ontology" (as the editors of this issue have put it). One would also want to hope that the dematerializing liquidity brought about by capitalism could be countered by the rematerializing effect of a corporeal imaginary that resists hygienicization, re-appropriation and functionalization. Thus, in the most general terms, it would be a plea for a materiality without reification.

\section{$* * *$}

To be sure, life is in many ways a matter of hydraulics. It consists in a regulation of flows, a circulation of matter. It requires (relatively) solid structures that contain, expel and exchange fluids. At a basic level, an organism may easily be envisaged as a tube or pipe - equipped with ever more sophisticated filtering systems - through which matter flows and gets processed or metabolized, "captured", as it were, and forced to yield its energy potential to the metabolizing entity concerned with its own self-preservation. In a Freudian framework, this intestinal tube would be an illustration of a sophisticated (if purposeless) "detour" from the ground level of "unlife" (cf. Beyond the Pleasure Principle). Life depends on the functionalization of (essentially fluid or at least fluidifiable) matter: it is a technology that hinders and deflects material flows. The filtering, immunological mechanisms are of crucial importance: they discriminate, select, and assimilate whatever the organic structure finds proper or eliminate that which is improper.

Arguably, only an ontology that presupposes functional, closed hydraulic circuits can claim to be a "leaky" ontology. (Unlike your kitchen tap, the sea cannot really "leak," though it certainly exists in a state of constant flux and exchange.) Onto-hydraulics (or the self-regulation of flows in and across the living and nonliving realms) would have to precede any specifically leaky (bio-)ontology one can think of. Yet a rheum-ontology (Greek rheuma = that which flows, flux, discharge from the body) could be posi-ted as prior even to onto-hydraulics. 


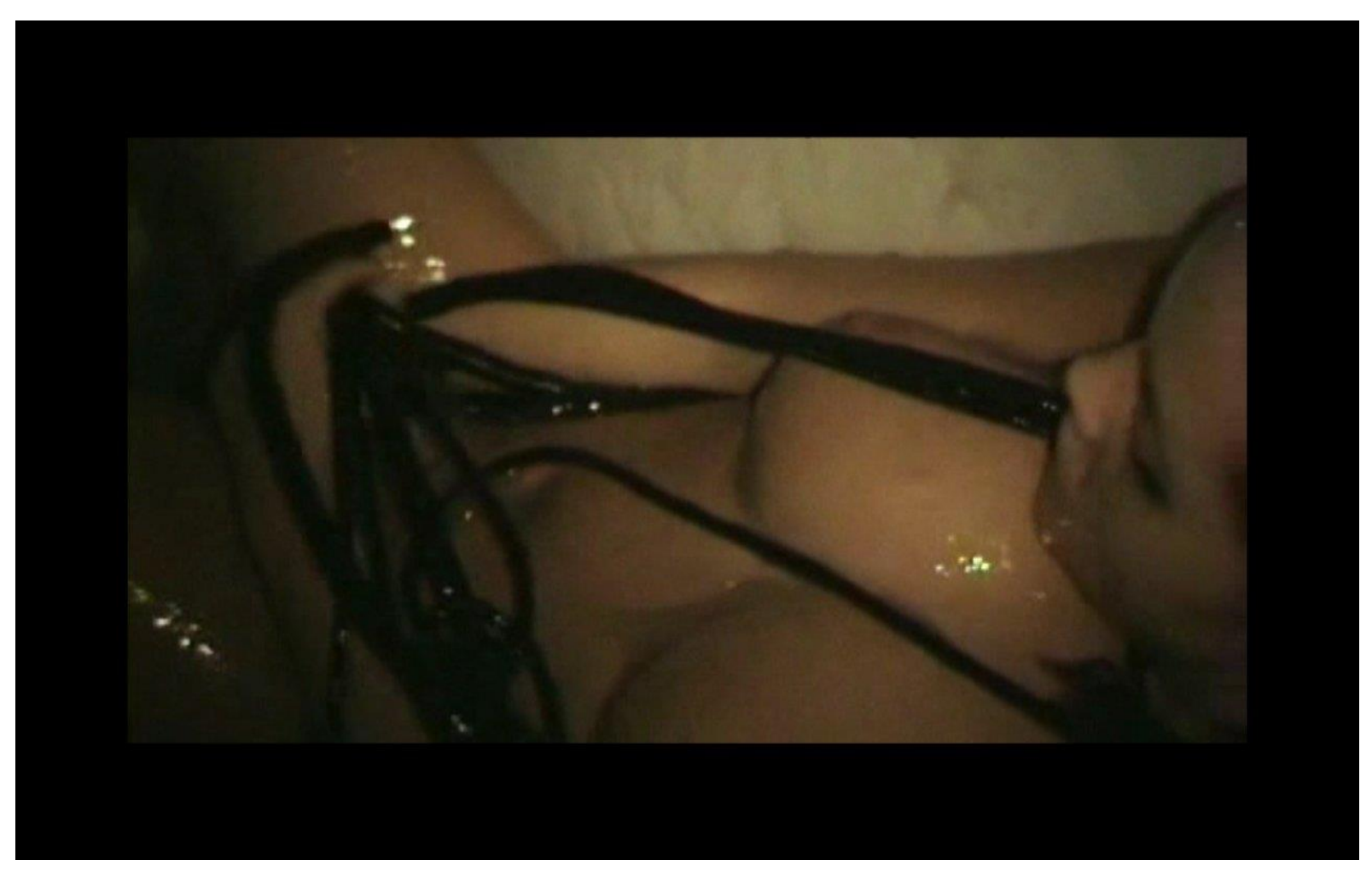

Ever since Hippocrates we have known that the human body is a vessel containing a mixture of four vital fluids: blood, phlegm, bile and black bile. Depending on their humoral proportions, they determine one's appearance (skin color), temperament as well as the equilibrium between health and illness (Porter and Vigarello 308-11). According to this theory of bodily humors, stemming as it did from mythical thinking, all kinds of fluids flow constantly through the human body, get absorbed and excreted, and thus regulate the vital processes inside the human system. In effect, fluidity was tied up with life-giving energy, while human life was imagined as a flowing river.

Freud described sexual energy along similar lines; his writing, as Katherine Hayles sums it up, "is shot through with hydraulic imagery, from blockages and dams to floods and eruptions. He images the libido essentially as a flow that must be regulated" (30). Jean François Lyotard would take this conceptualization up in his Libidinal Economy in order to rethink Marx through an energetics of libidinal flows. Our own conceptual trajectory in this essay owes more to the work of Deleuze and Guattari, where political thinking is also bound up with the concept of flows (of desire, of words, of matter, of information, of capital) - flows that regulate the lives of individuals and societies: "sperm, river, drainage, inflamed genital mucus, or a stream of words that do not let themselves be coded, a libido that is too fluid, too viscous" (Deleuze and Guattari 133). In the wake of George Bataille, 
who "dreamed of a society [...] of fluid exchanges and willing loss rather than a society of accumulation" (Noys), our "liquid modernity" (Bauman) seems to have adopted the Heraclitean mechanics of bodily and non-bodily fluids as one of the underlying metaphors for imagining the individual and the social. Everything flows, and so do bodies.

$* * *$

"Fluidity" tends to be conceptually reduced to water - that odorless, tasteless, low-viscosity, transparent liquid deemed necessary for any life to develop and maintain itself (just as liquidated money seems to form the basis of all social life in neoliberal capitalism, a universal solvent of all social relations). Yet bodily fluids are never just water: they are water-based solutions with different physical and chemical properties as well as different and complex cultural encodings. Beyond a simple division of the body's fluids into polluting and nonpolluting ones (cf. Grosz, Kristeva), the meanings of a given fluid are often contextual and ambiguous. Urine, for instance, is commonly perceived as "unclean," yet in folk medicine it is believed to have therapeutic effects, perhaps due to its associations with the body's self-purifying mechanisms and its allegedly antiseptic properties. Bodily excretions function as the kind of "dirt" that is necessary to keep the body clean: the catarrh is a cognate of catharsis; sweat, menstrual blood and urine all carry the stigma of "contamination" even as they are agents of purification. (Of the various excretions only tears seem to be free from contaminating associations.) Formulaically speaking, that which purifies is not clean. And/or that which claims to be clean maintains its cleanliness only by constantly producing dirt.

Carnal Fluidity is an experimental porn film produced in 2008 by the Polish collective INSIDE FLESH established by Sylvia Lajbig and Piotr Węgrzyński, the founders of the artistic group SUKA OFF active since 1995 (suka means "bitch" or "slut" in Polish). The film won the main prize at the 5th Porn Film Festival in Berlin in 2010. Since then INSIDE FLESH has had a regular presence at the Berlin festival, where it continues to screen its subsequent film projects: Possession 3 in 2011 and Doll Reconstruction (in the experimental porn category) along with Possession 6 (in the fetish porn category) in 2012. Carnal Fluidity was also shown in Sao Paulo at the PopPorn Festival and in Poland as part of the "Pornography Laid Bare" conference ("Obnażyć pornografię!") held in Katowice in 2011. The conference screening was followed by a discussion with the filmmakers, 
during which a leading feminist critic expressed her disgust at what she called the "hectoliters of sperm" which, in her view, flooded the movie.

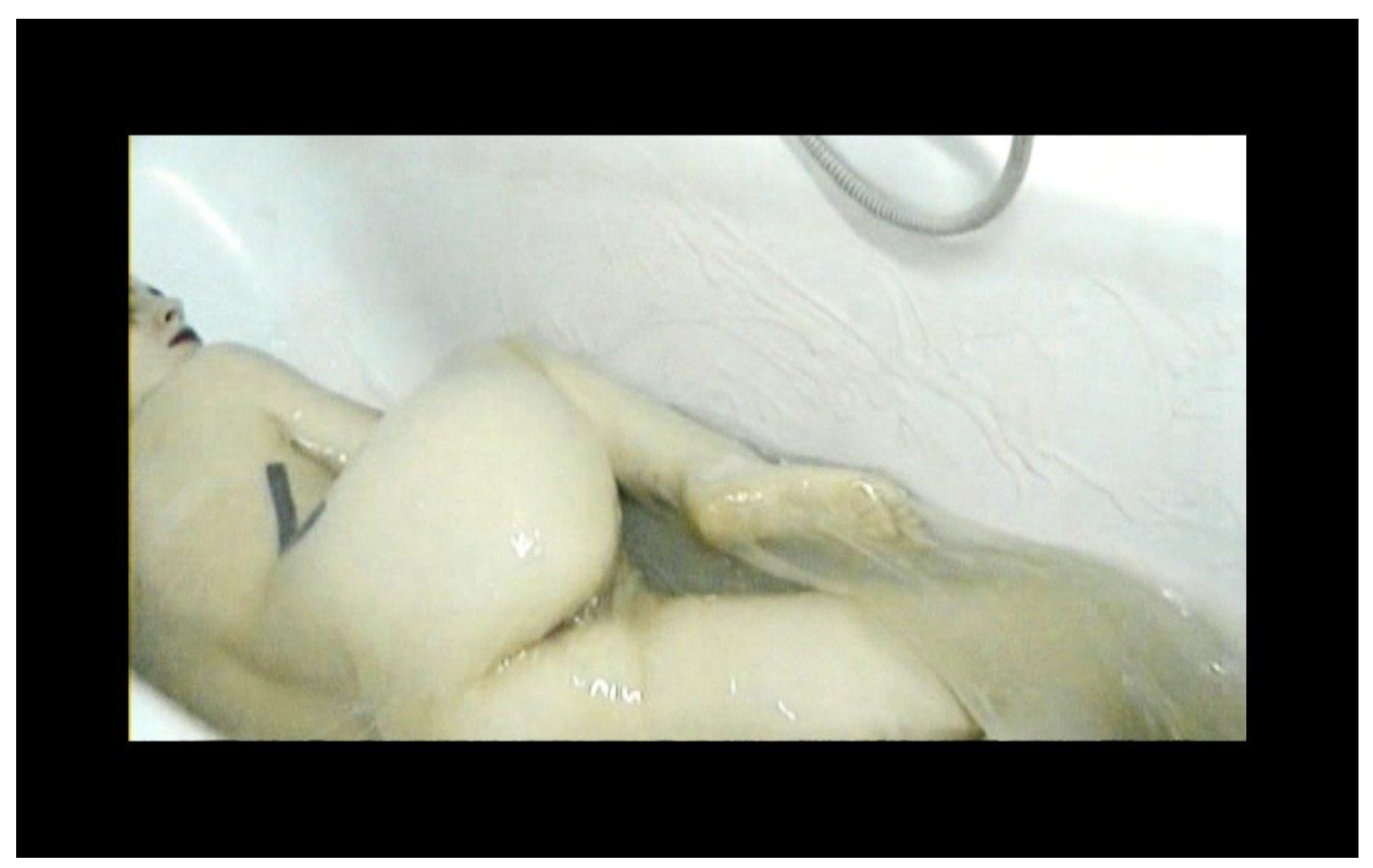

The "fluidity" was not meant here as a reference to "gender fluidity," changing one's identity in terms of sexual preferences. The man does not pretend to be a woman, nor the other way round.

In this case, the "remote control" of the whole process is a man closed inside his uniform. His penis is part of the costume. He is not a symbol (one may look at it that way, but it's a banal way of reading images), but a "hard" element of the mechanism. The woman, on the other hand, has more freedom, she moves across spaces, changes her appearance and her relations. She fluidifies and blurs meanings.

But I also talk about the filling up of the "vessel" of the human body with another body. This need for mutual complementation is precisely what stands behind the idea of "carnal fluidity." (AS) 
[A blurb on Carnal Fluidity:]

Story about the exchange of shapes, gender and space. The characters indulge themselves in ritual actions with use of modern media fetishes (TV screen and remote, photo booth) in order to satisfy their sexual needs. Their fantasies and projections (homo-, hetero- and auto-erotic in both male and female body) become real sexual acts. A postindustrial vision of isolation and loss of sexual identity. (http://insideflesh.blogspot.com/2010/01/carnal-fluidity.html)

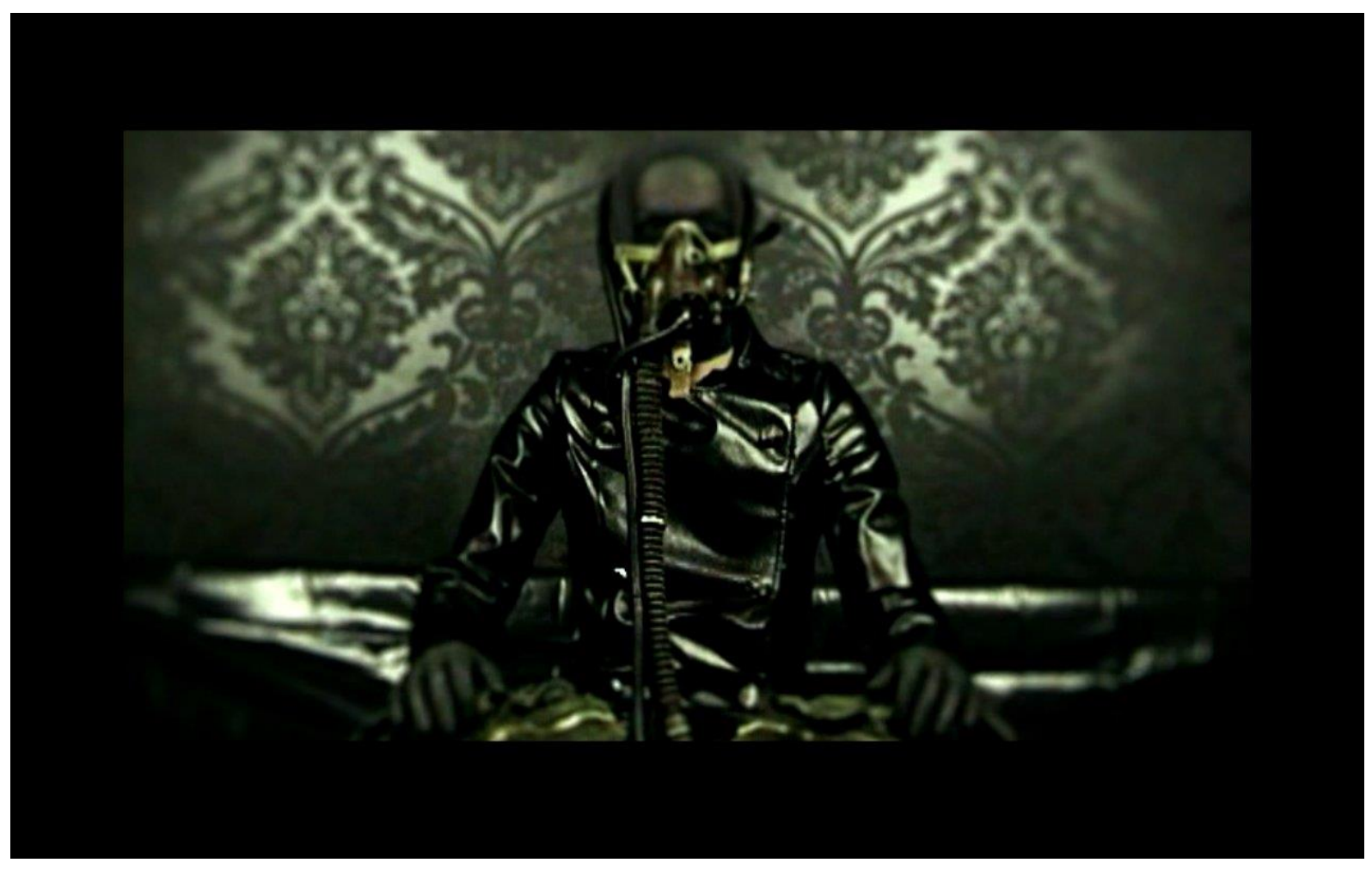

$* * *$

The artists' comments, found in different places, may sound somewhat confusing: on the one hand, they seem to adhere to a series of organizing binaries (solidity / fluidity, hardness / softness, and most obviously - male / female) and distance themselves from gender / sexual fluidity; but on the other, they emphasize the fluidity of their mutual relations, they speak of gender exchange and dissolution as well as "loss of sexual identity." Indeed, on its official website SUKA OFF declares that one of its goals is to "redefine the [sic] gender by blurring the individual attributes / sexual codes culturally arrogated to the male and female" (SUKA OFF website). 
One way this inconsistency could be explained is that the artists - who never miss the opportunity to emphasize their "anti-ideological" stance - do not intend to deconstruct the binaries in advance, from an established theoretical position, with a preconceived goal in mind. Instead, the fluidifications and exchanges happen by and along the way, as an unpredictable effect of sexual and aesthetic experimentations. While at the beginning "man" and "woman" are simply given, through various means of communication and exchange - fantasmatic projections, sexual play, fetishes, manipulations of the visual, etc. - the cultural, if not biological, information gets de-, reand overcoded. No longer "man and woman", but a composite mechanism - with various elements plugged in and out - that acquires its own mode of functioning, its own ephemeral "genetic code" or operating system. Individual bodies become extensions of a monstrous machine for the production of anonymous, inhuman sex; humans are no longer in any sense "subjects" of sexual activity, but rather are themselves subject to sexual mechanical flows and pulsations.

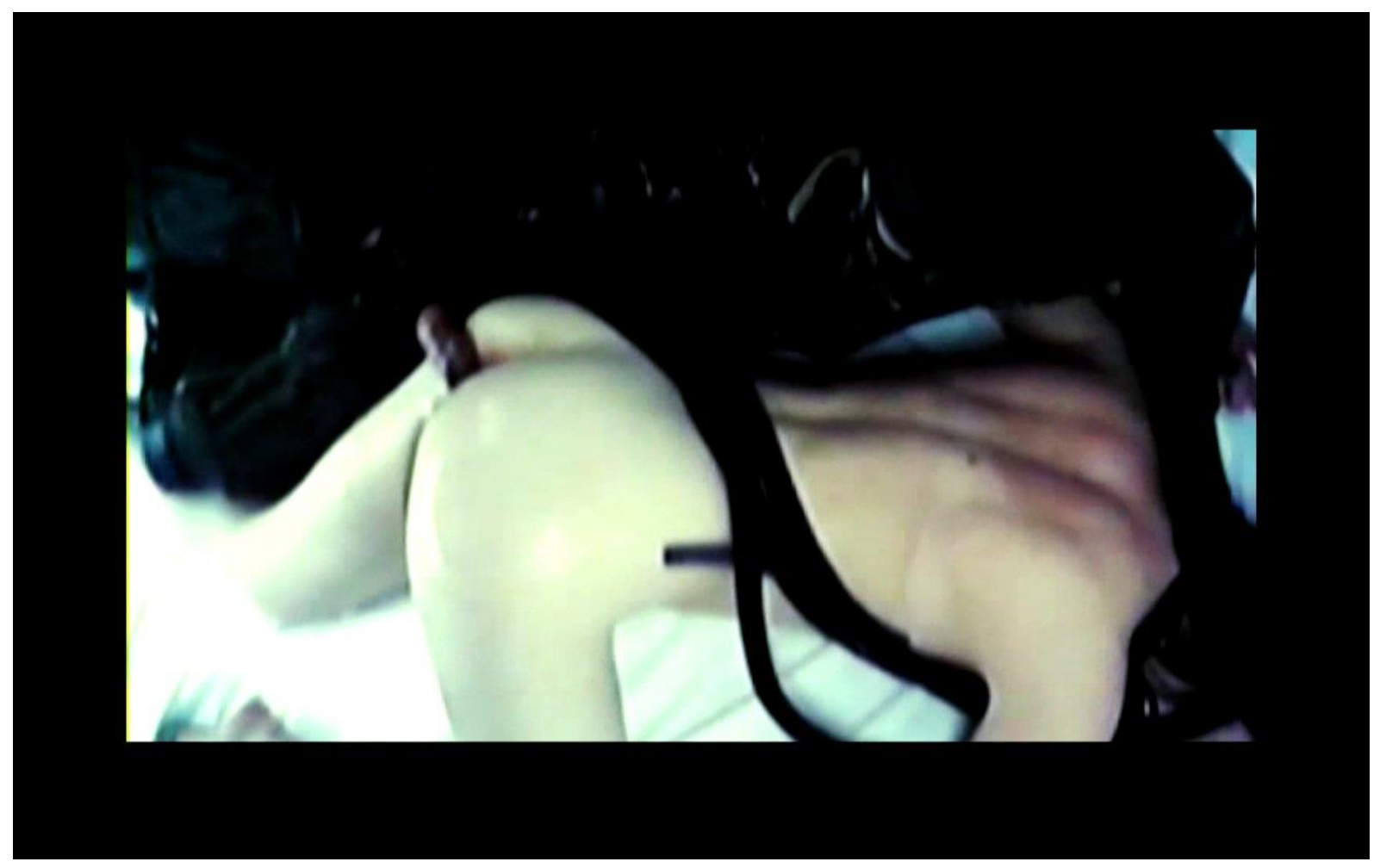

$* * *$

"Hectoliters of sperm"? So be it.

The artists avoid using liquids whose possible meaning - in their view - is too limited or univocal (i.e. urine, which only connotes "excretion, rejection of something that is redundant"; AS). They 
explain the use of synthetic substances in their projects - such as latex, silicone or acryl - by saying that such substances "avoid univocal interpretation" (Daultrey).

The nature of the mucous substance used in the extended bathtub scene (see some of the images dispersed throughout this essay), in fact, undecidable. Sperm or fetal fluids? Artificial or organic? What certainly draws the viewer's attention is its growing viscosity, which renders it more and more "abject," more and more constraining, almost suffocating (like a uniform?). Suppose it was sperm wouldn't its sheer volume contradict the heteropatriarchal economy of "sperm conservation" as opposed to the "feminine" or queer economy of dissipation and wastefulness? (Cf. Hayles 32: "[...] female sexuality has frequently been seen as autocatalytic [...] and radically nonconservative.") This polyvalence of the substance's possible readings may also be indicative of the excess that fluidity itself entails, unconcerned as it is with its own conservation (what is there to conserve?) even as it remains, in various ways, a necessary condition for any organism's self-preservation. Dissociated from social and biological (re)production, the viscous liquid - through both its semantic polyvalence and its sheer volume - evokes an alternative Bataillean (an)economy of surplus and wastefulness, of fluids rubbings against solids and other fluids beyond any conceivable utility.

The bodily fluids I [we] use most are saliva, sperm and blood - probably due to the rather dynamic way in which they can change their consistency and autoproductive capacities. There is something technological about these processes, so I put them together with other "inhuman" substances that possess similar properties. They get thicker or thinner, they dry out or degrade. (AS)

In her essay "The Mechanics of Fluids" Luce Irigaray draws on fluid mechanics on the one hand, and on Lacan's typology of the registers of subjectivity on the other, to (re)connect the feminine with fluidity. In her view, the Lacanian Symbolic, characteristic of the phallocentric logic, is founded on the mechanics of solids, which envisages an integrated and sealed system of communicating vessels, a world of precise concepts and definitions that defends its borders and essentially reflects the Cartesian ideal of "male" rationality, which forecloses all fluidity, all leakage, all nonsystemacity. If so, the fluidity that is identified with femininity disturbs the Symbolic order and constitutes an 
intervention of the Real. Feminine fluidity is a manifestation of a formless excess that cannot be contained and "pours over."

Of course, I make the distinction between male and female fluidity, even though the quality is more commonly attributed to women. The phrase "carnal fluidity" refers metaphorically to the dissolving of information about gender, not simply in the social realm, but rather in the aesthetic one. Probably that's where the motif of isolation and alienation, inscribed in an industrial setting, comes from. (AS)

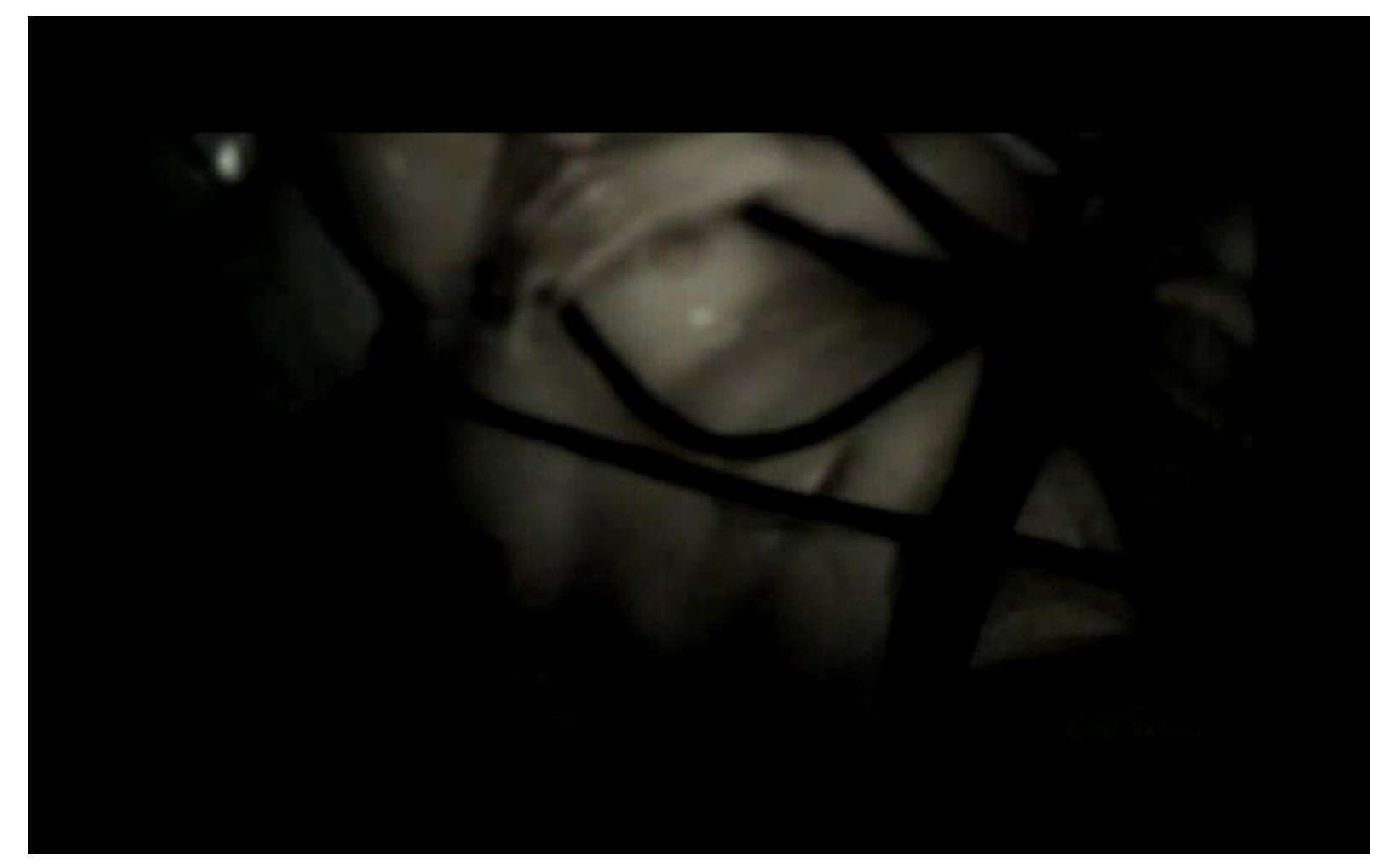

"The new vision of porn" created by the INSIDE FLESH collective, and particularly by the film Carnal Fluidity, problematizes the division suggested by Irigaray. Is there a "male" fluid mechanics? Must an ejaculating penis, as shown in the final scene of the film, be always equivalent to male domination? How does the image relate to the eruptional excess, the "spilling over" associated with female fluidity? Is this male fluid - so bound up with the idea of reproduction - always more ennobled than female fluids, especially when used non-procreatively? And does the phrase "hectoliters of sperm," in its emphasis on eruptive excess, point to male or female fluid mechanics? 
Situating herself firmly within feminist studies, Irigaray undoubtedly essentializes, and in a sense even appropriates or fetishizes the notion of fluidity by ascribing it exclusively to women (lactation, menstruation, tears). At the same time, male fluidity is culturally repressed: softness and tearfulness are forced out by the imperative of being hard and stable, which Irigaray fails to notice. Male fluidity is being reclaimed in queer theory, which stresses the idea of dissolving identity rather than its consolidation (Epps 413).

The film includes scenes in which the action falls outside of direct phallic activity. These are the scenes where the actress derives pleasure from contact with the fluid essence of her own body. In the bathtub she turns into carnal mucus. This fluid or mucus (in reality fluid latex) that the woman immerses herself in looks very "carnal," like dissolved skin. The skin no longer separates the wet inside from the dry outside. The flesh is turned inside out, it dissolves in water, it becomes watery even as the water becomes fleshy (it warms and, uncannily, thickens up to the point where it acquires the quality of a "second skin," or a tight uniform). The body's viscosity is what the scene irresistibly evokes.

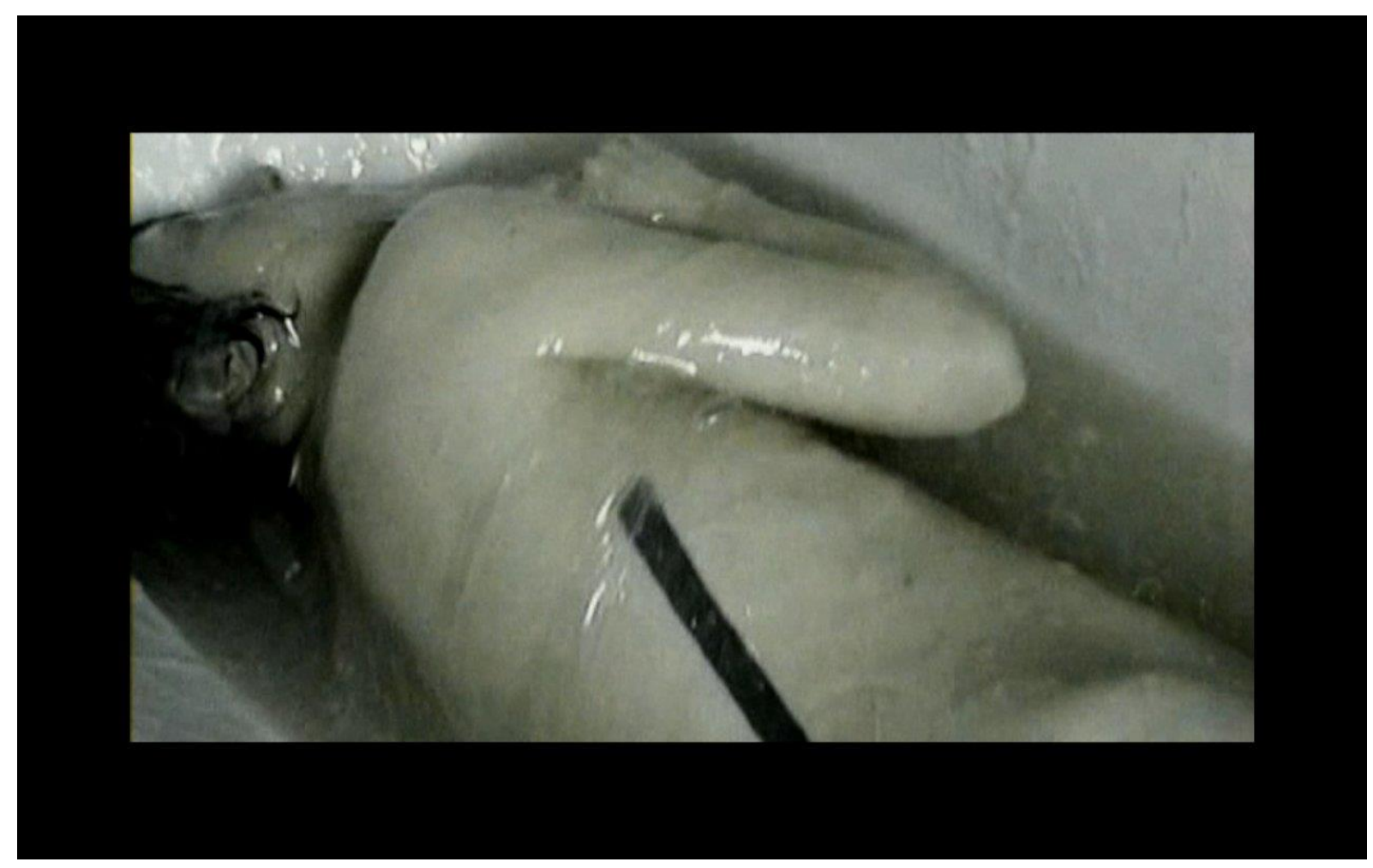


As Mary Douglas has observed in her commentary on Sartre's Being and Nothingness, viscosity is an intermediary state between fluidity and solidity (79), so that it transcends the solid/ fluid opposition, and consequently the male/ female one. It is precisely viscosity - which is neither solid (male) nor fluid (female) - that turns out to be the most repulsive and dangerous. Contact with a viscous, sexually undifferentiated substance triggers primal anxiety over the dissolution/ decomposition of one's own body. Possibly what the author of the "hectoliters of sperm" comment (see above) found the most disturbing and terrifying was nothing else but viscosity: a quality shared by both fluid latex and sperm.

It seems that evoking fear or terror (not only through viscous fluids) is one of SUKA OFF's principal goals. A major focus of their artistic explorations is "the virus of violence and fear symbolized by synthetic fluids (liquid latex / acrylic paint)" (SUKA OFF website). According to the artists, the fascination with masks, uniforms, chains and other accessories that fetishize violence was an allusion to the oppressiveness associated with the activity of terrorist groups (originally the SUKA OFF collective bore the name Teatro La Terrorisma Suka Off; see "Zrzucanie skóry" 137). The idea of terror as a primal affect that manifests itself in anxiety, panic or fear, may be understood in this context, after Eagleton, in relation to the notion of sublimity as expressed in the Dionysian orgy. In Eagleton's words, Dionysus was "one of the earliest terrorist ringleaders" (2). In Carnal Fluidity the variously evoked terrors are tantamount to the Dionysian transposition of sexual violence into sublimity. Terror and sexual bliss have also been linked in the exegesis of Lacan's psychoanalysis offered by Slavoj Žižek, who writes of the "horrifying jouissance" (212) in relation to the "subject presumed to enjoy" (186). From this perspective, sexual enjoyment triggers fear in the same sense that pornography triggers a moral panic. (In 2005 SUKA OFF was charged by one of Warsaw's city councillors with publicly propagating pornography.) It is not so much the sexual intercourse which, according to Lacan, does not exist - as the fantasy (scenario) attached to it that exposes the obscene jouissance: impossible and unattainable, yet persistent and necessary.

But isn't the bathtub scene, after all, subservient to the logic of a voyeuristic straight male fantasy? Or take the homoerotic scene involving the two actresses: does it really go beyond the rules of phallocentric domination? Would a similar scene between two men have a similar meaning? Would it be possible at all for such a scene to appear in a movie created by the INSIDE FLESH collective? 
Granted, the film suggests itself as a masturbatory male fantasy (locked into a frame narrative) organized around what seems like predominantly phallic imagery. It is the anonymous man in the uniform who creates and "remote controls" the settings, the female personae, the situations. The man's erect penis occupies the one static, central, regulatory position around which everything else flows and fluctuates. While the artist(s) claim(s) that the penis is just another element of the uniform, a pipe among other pipes, it is not exactly the case: the penis visually stands out and the numerous close-ups point to its privileged position. The film ends, predictably perhaps, with the man's self-induced ejaculation, thus confirming his apparent self-sufficiency and self-control as well as his master position. The impermeable, impenetrable uniform, which covers his whole body and renders him anonymous and, perhaps, cyborged, does not - or so it seems - trouble or erase the gender codings of "maleness"; instead, it lays them bare, it strips them down to the phallic core. The anonymity might rather be said to stress the universality of the Phallus. The rest of the man's body is incidental, a mere prosthesis (as is the body of one of the female characters, immobilized and stiffened with fetishistically employed medical prostheses). Far from being an individual's attribute or, worse, "capital" to be managed for the sake of maximizing pleasure (and/or power), sexuality is exposed here as the masturbatory mechanism of the (non-existent) Phallus for which variously gendered and variously empowered bodies are nothing but subsitutable prostheses.

Granted, the gender positions in Carnal Fluidity are asymmetrical and, at least at first sight, the film does not seem to attempt to decentre the phallic imaginary that organizes the (fluid) relations between persons, objects and images. Like most straight porn, ultimately the movie revolves around a (hydraulically achieved) hardness that leads to the male ejaculation, the fluid sterilely discharged onto the rubber or latex uniform.

The hardness I talk about is important in mechanical terms. Preferably, it should be accompanied by soft forms. I like all industrial-corporeal analogies. A hard penis penetrates a soft vagina, which causes the production of fluids. This sounds like a description of a technological process, doesn't it? My intention is not dehumanization, but changing the meanings and applications of the discovered processes and the fluids that accompany them. I use real objects to image unreal situations. (AS) 


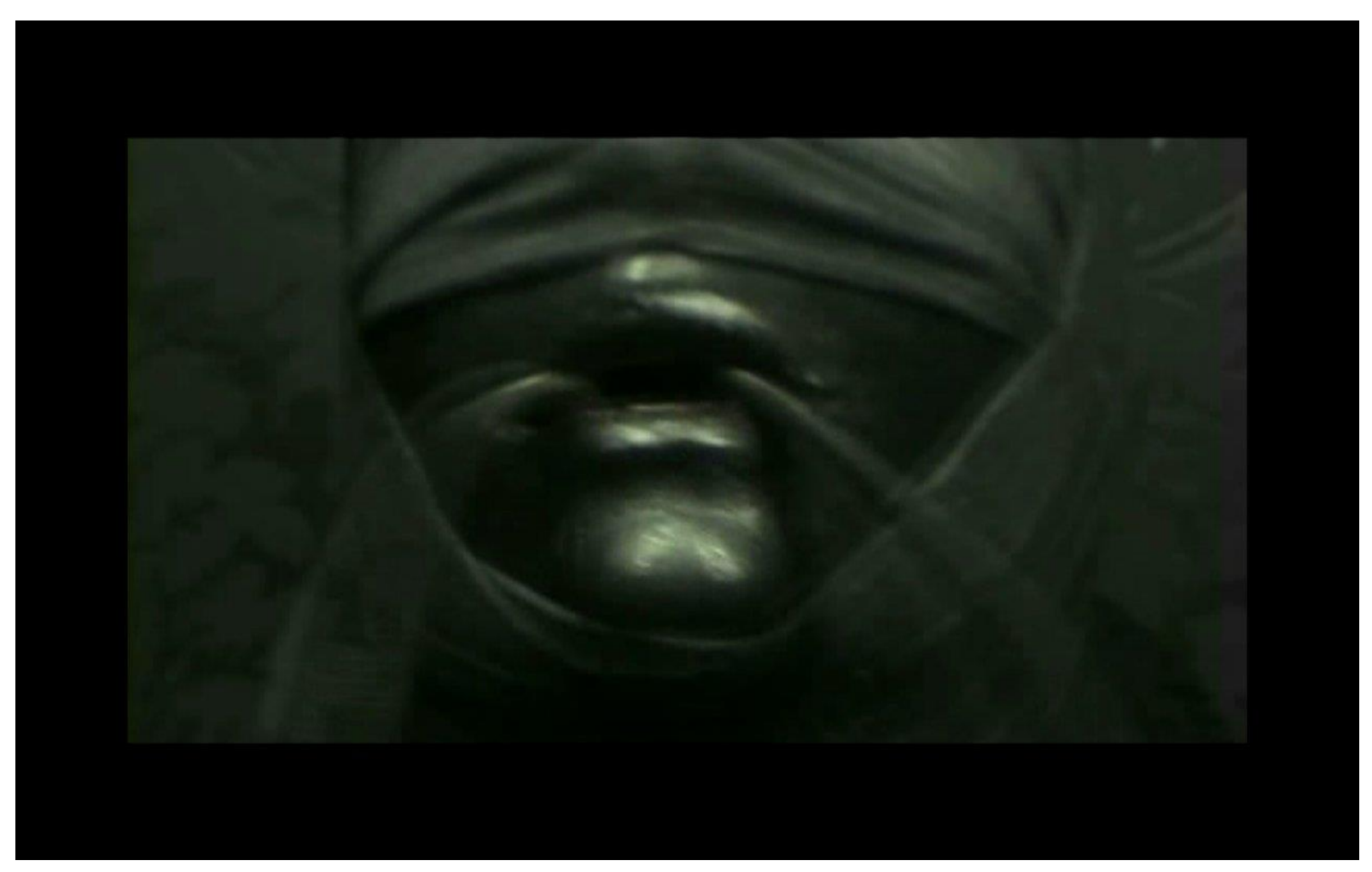

Having said that, however, one should also be ready to acknowledge that the universalization of the Phallus (together with the privileges customarily attached to it) becomes, in effect, the man's prison. Exactly halfway through the movie the male character tries to (partly) free himself from his hermetic confinement: he takes off his mask and cuts some of the bandages around his head to expose his mouth; hoses appear and get into his mouth and further down his body (followed by the camera). Not only is the tearing off of the mask an (unfinished) gesture towards a deuniversalization and a singularized subjecthood, it also opens the man up to (molar as well as molecular) communications and penetrations. The communications take place at various levels simultaneously: it's the communication between (or across) different elements of the body, between (or across) persons, between (or across) sexes and genders, between (or across) codes and meanings. Communication flows enable assemblages to aggregate. Still, this opening up of a male body for penetration is not unconditional: anal penetration seems to remain a strong taboo in the work of the INSIDE FLESH collective: the last frontier defending and defining the "male" against the "female." The male craving for penetration is clearly present in SUKA OFF's productions, yet certain kinds of penetration remain (as yet) impermissible or at least unrepresentable.

Although phallic imagery features prominently throughout the film and may indeed claim to symbolically organize the flows of fluids, bodies, desires, genders and images, it ultimately fails to 
establish a "totality" that would delegate each element to its "proper place." Rather, much as it claims to be in the position of dictating "the rules of the game," the phallic function is itself subjected to sexual play where no one is ever able to become a proper "subject." Arguably, in pornography a (liberal humanist) subject is never possible - which is perhaps why pornography remains a scandal even in "liberal" Western societies. In Lee Edelman's formulation, "[a]s a genre insistently focused on parts, it exposes, along with the private parts, the parts of ourselves incompatible with the sovereignty of the whole and so with belief in the 'private self' as the property of the subject" (32). Indeed, "the common labor of pornography and the queer is "the universal desublimation of universality against which universality first establishes itself" (Edelman 33).

As Linda Williams admits, "it is simply not possible to regard a represented penis per se as a literal instance of male dominance" (268). The cumshot - traditionally associated with a triumphant confirmation of male potency and domination, the hero's trophy - may likewise escape the dominant phallic order. Indeed, the cumshot that concludes Carnal Fluidity is not very convincing by the standards of the mainstream porn industry. It could be described as "weak" and "leaky," and thus "feminine" rather than "masculine." The autoeroticism of this scene is obviously autoironic, a parody of the cumshot convention. Moreover, as Calvin Thomas argues in his analysis of the "money shot," semen gets feminized simply "by virtue of being subjected to representation" or made visible (19). 


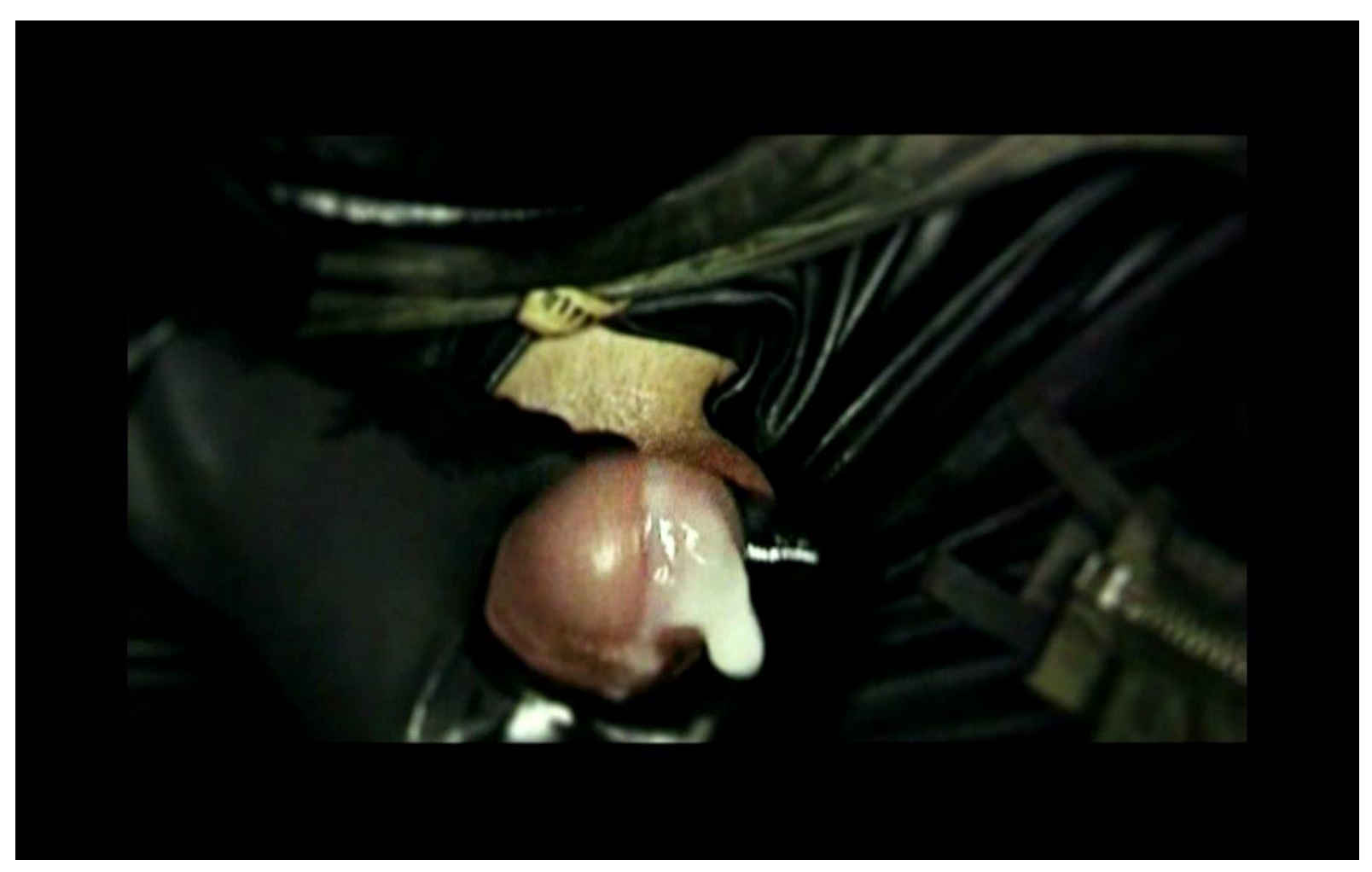

Lee Edelman observes that "[in]n the rigid dick the vital flow succumbs to rigor mortis, to a sort of mortification, to the solidity of what Deleuze evokes as the wall of representation or 'the statue of the father,' which immures the material flow he describes as 'a formless, nonhuman life'" (39). Yet something always escapes this mortification, some molecules of that "formless, nonhuman life" leak out and disconnect sperm from the sanctified notion of human "essence" or "spirit." As a material, viscous fluid, cum redirects us not only to the idea of "male fluidity," but, further, to the nonhuman sexless fluidity that underlies the existence of liberal humanist subjects. The conscious ego-subject, in Edelman's analysis, becomes "nothing but the largely indifferent, if necessary, adjunct" to the production of jouissance (38), a point that brings us back to the inhuman, machinic quality of sexual behavior in Carnal Fluidity.

Even though Carnal Fluidity does not seem to openly undermine phallocentrism, it certainly sexualizes it to the point where its claims to power dissolve in the excessive fluids, organic or artificial, which dominate the movie. Rather than claim, in the good old liberal humanist tradition, gender equality, mutual respect, partnership, tolerance for sexual difference and all that, the film adopts the strategy of a playful sexualization of existing gender/ sexual/ social relations, thus undermining their claims to "naturalness" and teasing out of them their latent potential for (ever 
politically incorrect) jouissance. This is a "politics" akin to that of SM practices: rather than deny power differentials - however culturally constructed they may be understood to be - let us neutralize them through sexual roleplay. This is, more generally, the kind of cultural work, or cultural politics, that pornography performs. "Pornography," as one of us has written elsewhere, "does not propose a definitive concept of the body; instead, the body remains inevitably fluid and infinitely able to reinvent itself and its capacity for pleasure." And further:

Here is play of power before it comes to be fixed into stable social roles; before it becomes coercive, reified, and institutionalized. Even when it borrows from the grammar of violence, sex in pornographic representations remains irredeemably playful. Much of its allure comes from the fact that it shows a world without the law: the only raison d'être of a police(wo)man or a soldier in this world is the fetish quality of his/her dress and his/her affinity with power. Any figure appropriated from the "ordinary" world loses its "real" meaning and becomes a prop, a "false signifier" pointing not to fixed social positions, but to the pleasurable playfulness behind social existence. (Sikora)

Along somewhat similar lines, Lee Edelman proposes that pornography, like queerness, "never coincides with itself, never quickens into form" (38).

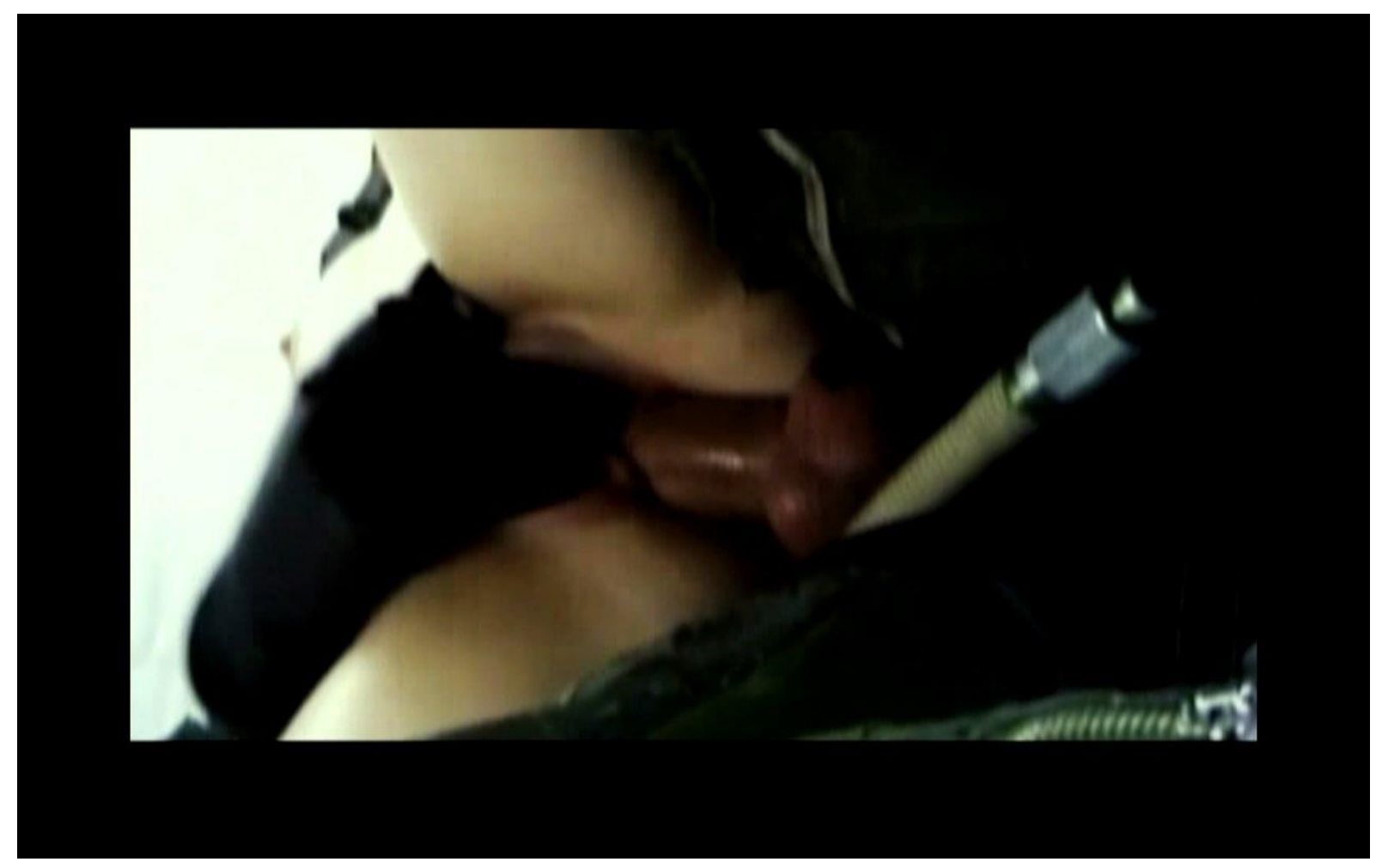


When feminism(s) or the LGBT movement(s) seek "integration" into the liberal model of "clean and proper" subjecthood, what ensues - as we have been able to observe over the last few decades - is a desexualization and decorporealization; or, more precisely, an increasingly intense regulation and disciplining of bodies, genders and sexualities - which is the price to pay for "inclusion" and "recognition."

So much depends on (the denial of) literalization.

We've have had some problems with people who take what we do on stage literally. One man in Geneva became aggressive during the 'Flesh Camp' performance [features concentration camp metaphors], because he believed that Piotr was promoting Nazism and violence against women. (Daultrey)

Baudrillard claims that porn "adds a dimension to the space of sex, it makes the latter more real than the real" (28). This surplus of reality makes the hyperreality of sex apparent and thus brings porn to the level of a simulacrum. In Carnal Fluidity the sexual scenes focus on exposing the mechanics, the physiology, and even the hydraulics of sex. Bodies are shown as "desiring machines" interconnected through a network of flows, hoses and pipes. Fluids serve here as lubricants, while the penis works like a piston or a pump. The pipes and hoses, inserted into the mouth, the vagina and the anus, are an extension of the ducts of the human body: the gullet, the intestines, the veins. They connect the (interior of the) body and the world, biology and technology. The pilot's mask, the bathtub, the rubber hose, the drain, the sewers, the communication channels, the corridors, the photo booth, the bathroom, the bedroom make up a system of communicating vessels where fluid bodies try to communicate with each other. The trains penetrating the subway tunnels, the penis entering the vagina, the streams of people vanishing into passageways and carriages demonstrate some sort of a fluid mechanics of the modern world, the world of Bauman's "liquid modernity." Sex is just one of many fluctuating dimensions of the hyperreal mechanism of communication. 
In a world of isolated, self-contained objects no communication, and no sexuality, would be possible. Communication depends on seepage, flow and exchange.

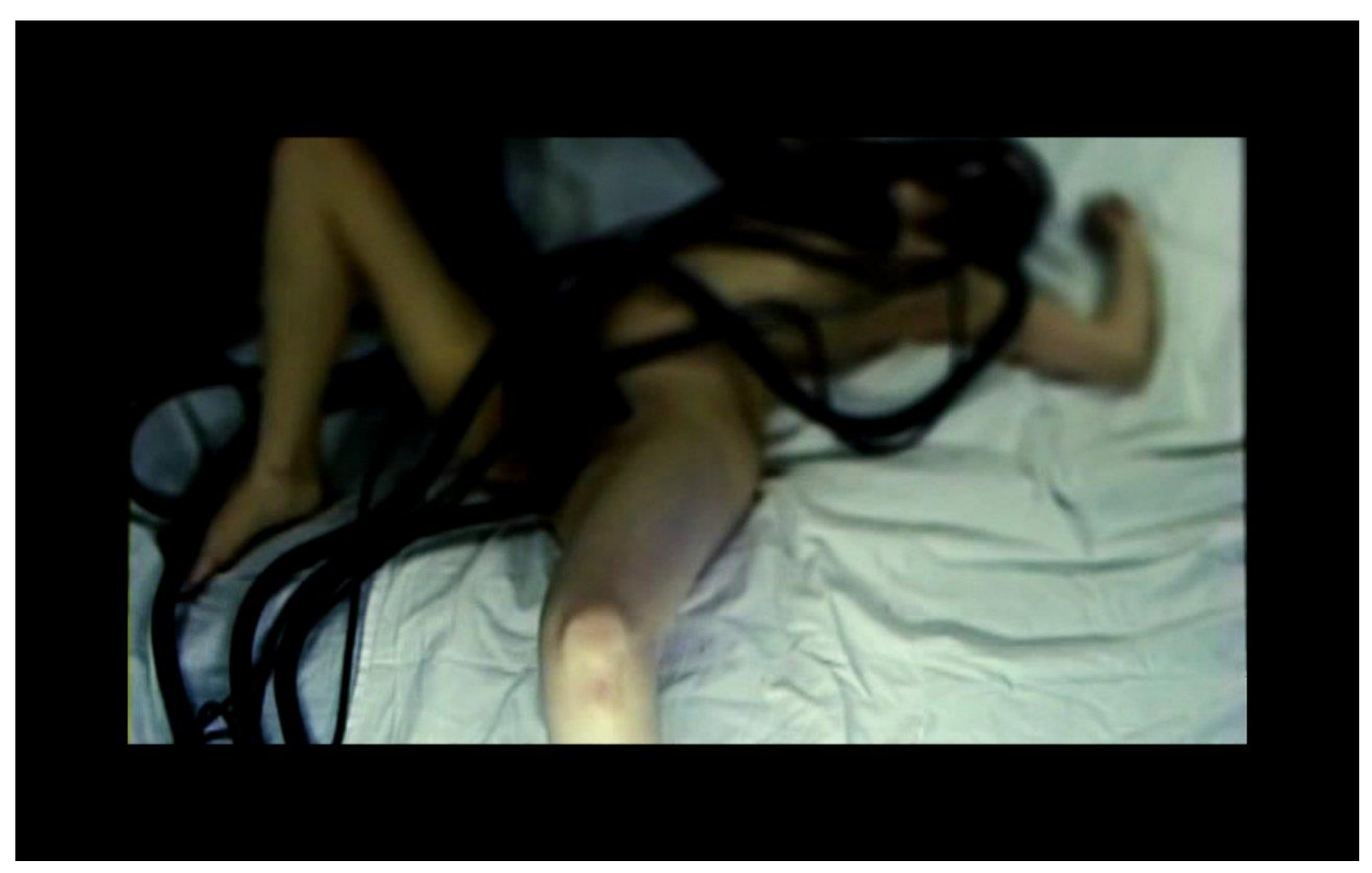

The sexual intercourse is portrayed in the movie through the figure of the bodies' plugging in rather than uniting, as in classical porn. The bodies are plugged into each other with numerous pipes and appliances. Interestingly, they also seem to be plugged into the camera and the monitor that displays them. The figure of plugging in suggests a mutual transfusion of fluids which, importantly, connects, but does not fuse the two organisms. The exchange/ transfusion of organic fluids brings to mind a number of vital questions concerning, for instance, safety and immunology. Primarily, however, it allows us to consider bodily fluids as well as the sexual act itself in terms of gift or exchange, which renders untenable the tendency to treat pornography solely in terms of the male economy of exploitation.

As Isabelle Stengers and Didier Gille argue, "the exchange of body fluids is dangerous; it is dangerous like life itself, which does not move in a closed circle, but as an endless flowing in and out of things" (Stengers 235). Arguably, the exchange of fluids is as dangerous as sex or breathing; it triggers unpredictable immunological responses, or indeed a breakdown of the immunological defense system as a whole. This danger makes it possible to think one's life as a gift offered to 
another through sex. If the gift takes the form of a fluid, then the risk arises that the life-giving gift is at the very same time a deadly poison (Dean 74-5). This is the ambivalent logic of the gift practiced in the culture of barebacking as well is in the movie created by the INSIDE FLESH collective, where sex is performed without a condom.

$* * *$

The movie picture is also a stream whose continuity is subjected to a variety of modifications: slowdown, speed-up, pause, rewind. The flow of the action is disturbed by various image distortions that produce a spilling or lingering effect: noise, deformation, flickering, loss of focus.

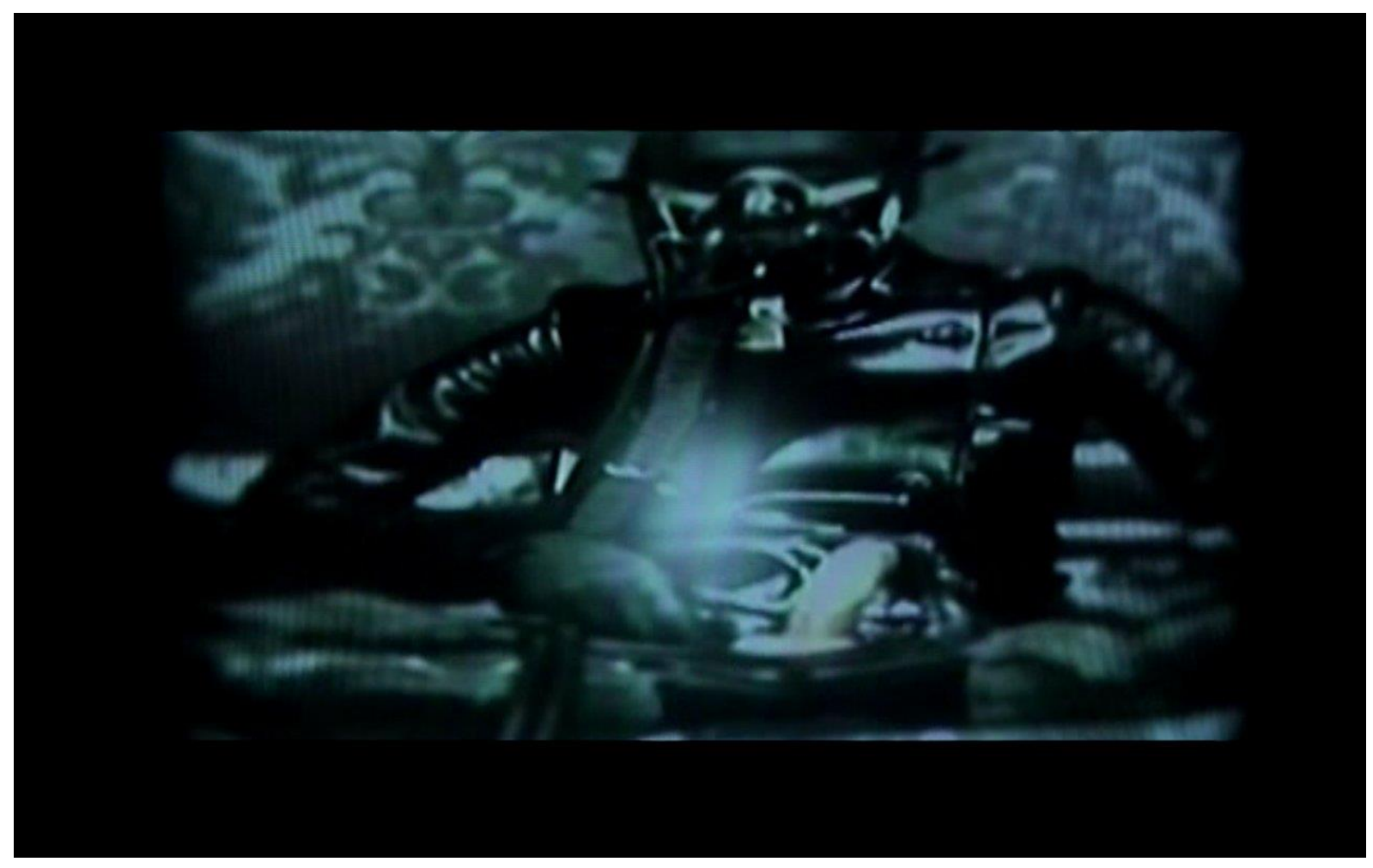

Frederic Jameson asserts that "[...] the visual is essentially pornographic [...]. Pornographic films are thus only the potentiation of films in general, which ask us to stare at the world as though it were a naked body" (1). It is the visual side of their work, the "visual language" - much more than its pornographic capacity to incite sexual arousal - that the artists keep emphasizing.

The key to the phrase "the new vision of porn" is the word "vision." Hypernarration in the plot structure needs dynamism in the visual realm. The films I make are not meant to sexually arouse the viewers (which is the chief aim of mainstream productions); they 
are not meant to be an equivalent to any sexual activity. Well, at least not primarily:) (AS)

When watching Carnal Fluidity, the viewer inadvertently becomes part of another assemblage, another machine: the one that produces meanings out of the visual, out of configurations and processions of (variously prepared) images. Even though the artists distance themselves from "symbolic" readings of their works and instead emphasize the formal dimension and the visual codes, any image, any formal device, any prop is bound to be subjected to the cultural imperative of "interpretation." On the other hand, Caroline A. Jones argues, "while we now (in our late capitalist postmodern era) 'know' that everything is a simulacrum, an image, a representation, we also 'know' that this simulacral world always leaks. Something always escapes the image" (136). Instrumentalized communication always leaks. Pornographic images in general, and SUKA OFF's pornographic images in particular, are equally about communication possibilities and communication breakdowns. As one of us has claimed elsewhere, "through pornographic abjection the Lacanian 'Real' flashes through, pointing to a moment of crisis, a communication breakdown, a shameless parade of material signifiers released temporarily from the usual structures of meaning and social contracts" (Sikora).

With all due respect to the persistent and inevitable demands of hermeneutics, it is the leakages from the Symbolic that elicit visceral responses. There's more to communication than the "official" communication channels can hold; there's secret hydraulical exchanges, there are molecular flows that escape any subsumption to an abstract (phallic) symbol or an articulable politics.

\section{Bibliography}

Baudrillard, Jean. Seduction. Trans. Brian Singer. Basingstoke: Macmillan Education, 1990.

Bauman, Zygmunt. Liquid Modernity. Cambridge UK: Polity Press, 2000.

Carnal Fluidity. INSIDE FLESH, 2008. For details see: <http://insideflesh.blogspot.com/2010/01/carnal-fluidity.html>.

Daultrey, Stephen. An interview with Suka Off. 2007. < http://www.bizarremag.com/film-andmusic/interviews/5793/suka_off.html>. 
Deleuze Gilles and Felix Guattari. Anti-Oedipus. Capitalism and Schizophrenia. Trans. Robert Hurley, Mark Seem, and Helen R. Lane. Minneapolis: University of Minnesota Press, 2000.

Dean, Tim. Unlimited Intimacy. Reflections of the Subculture of Barebacking. Chicago and London: University of Chicago Press, 2009.

Douglas, Mary. Purity and Danger. London: Routledge, 1966.

Eagleton, Terry. Holy Terror. New York: Oxford University Press, 2005.

Edelman, Lee. "Unbecoming: Pornography, Posthumanism, and the Queer Event." Post Porn Politics. Ed. Tim Stüttgen. Berlin: B Books, 2009.

Epps, Brad. "The Fetish of Fluidity." Homosexuality and Psychoanalysis. Ed. Tim Dean and Christopher Lane. Chicago: University of Chicago Press, 2001. 412-431.

Freud, Sigmund. Beyond the Pleasure Principle. Trans. and ed. James Strachey. New York: W. W. Norton, 1961. 13 Sep 2010 <http://www.questia.com/PM.qst?a=o\&d=23246025>.

Grosz, Elizabeth. Volatile Bodies: Toward a Corporeal Feminism. Bloomington, IN: Indiana University Press, 1994.

Hayles, Katherine N. "Gender Encoding in Fluid Mechanics: Masculine Channels and Feminine Flows." Differences: A Journal of Feminist Cultural Studies 4.2 (1992): 16-44.

Irigaray, Luce. This Sex Which Is Not One. Trans. Cathereine Porter with Carolyn Burke. New York: Cornell University Press, 1985.

Jameson, Frederic. Signatures of the Visible. London and New York: Routledge, 1992.

Jones, Caroline A. "Decorporealization." Sensorium: Embodied Experience, Technology, and Contemporary Art. Ed. Caroline Jones. Cambridge, Mass: MIT List Visual Art Center and MIT Press, 2006.

Kristeva, Julia. The Powers of Horror: An Essay on Abjection. Trans. Leon S. Roudiez. New York: Columbia University Press, 1982.

Lyotard, Jean- François. Libidinal Economy. Trans. lain Hamilton Grant. Bloomington and Indianapolis: Indiana University Press, 1993.

Noys, Benjamin. Georges Bataille: A Critical Introduction. London: Pluto, 2000.

Porter, Roy and Georges Vigarello. Ciało, zdrowie i choroby [part 7]. Historia ciata. Vol. 1. Od renesansu do oświecenia. Ed. Georges Vigarello. Trans. Tomasz Stróżyński. Gdańsk: Słowo/Obraz Terytoria, 2011.

Sikora, Tomasz. "Liaisons Dangereux: Pornography, Modernity, Power." NMEDIAC, Journal of New Media and Culture 7 (2010). <http://www.ibiblio.org/nmediac/fall2010/liaisons.html>.

Stengers, Isabelle. Power and Invention: Situating Science. Trans. Paul Bains. Minneapolis: University of Minnesota Press, 1997.

SUKA OFF website. <http://www.sukaoff.com/indexeng.html>. 
Thomas, Calvin. Male Matters: Masculinity, Anxiety, and the Male Body on the Line. Chicago: University of Illinois Press, 1996.

Williams, Linda. Hard Core. Power, Pleasure, and the "Frenzy of the Visible." Berkeley and Los Angeles: University of California Press, 1989.

"Zrzucanie skóry. Rozmowa z grupą SUKA OFF." Trans:wizje 2011, nr 1.

Žižek, Slavoj. The Sublime Object of Ideology. London and New York: Verso, 2008. 